\title{
Risk analysis of oil transportation from the Persian Gulf to America in connection with the Suez Canal reconstruction
}

\author{
Larisa Pershina*, Liudmila Astreina \\ Admiral Ushakov Maritime State University, Department of Ship Navigation, 93 Lenin’s avenue, Novorossisk, 353918, Russia
}

\begin{abstract}
The tonnage capacity of the Suez Canal has almost doubled since its reconstruction. The risk analysis of oil and oil products transportation is carried out in the paper, considering this factor from the Persian Gulf to America, and in order to reveal the economic efficiency of the existing recommended routes. According to the research outcomes and calculations, it is proved that the most expensive path is the route through the Suez Canal. It can be profitable on a short haul for transportation to the countries of the Mediterranean Basin and Western Europe due to the low tariff plan for small vessels of the LR1, MR, Handymax, Handysize classes and doubling the freight by reducing the transit time over short distances. An analysis of the probable routes from the Persian Gulf to North America through the Suez Canal and bypassing Africa is carried out in the paper. The economic effect calculation of oil transportation is conducted using the example of the Sea Vigor tanker of the Suezmax class through the Suez Canal and the Cape of Good Hope, considering the distance, the cost of escorting ships through the Suez Canal, the risk assessment and cost of ship security services, the calculation of wind-wave losses of routes bypassing the African continent. Besides, the conclusions and recommendations are formulated in the paper.
\end{abstract}

\section{Introduction}

Frequently, the key issue in choosing the most rational (optimal) transportation option is the economic effect calculation of all stages of the voyage assignment, starting with the vessel load and the cargo transportation from the unloading berth. The specific conditions of transportation and the voyage tasks determine the efficiency criteria choice. Local (particular) and generalized (complex) efficiency criteria can be distinguished.

If the compared sea routes differ only in one taken indicator, then the local efficiency criteria are applied, excluding the downtime of vessels in the port while waiting for a queue or favorable weather conditions. In this case, the effectiveness of the compared sea routes can be assessed by one indicator: the company's costs of downtime at the points of loading and unloading, or the costs associated with the vessel empty return.

Complex performance indicators are used when the compared routes have several characteristics of the transport process. For instance, such parameters as: deadweight of a vessel, downtime under loading and unloading, specific fuel consumption per route, costs of paying transport tariffs and other charges arising on routes, costs of safety and integrity of cargo, vessel and crew.

In our case, any particular criterion is not enough. We will try to go into the matter applying complex criteria and formulating conclusions.

\section{Methods and materials}

The world oil and gas basins and the role of the Persian Gulf in the world's fuel industry are studied to analyze the routes' efficiency, the main cargo flows of oil from the Persian Gulf are considered. Weather conditions for the selected routes are analyzed. The economic effect of oil transportation is calculated through the Suez Canal and the Cape of Good Hope considering the distance, the cost of navigating ships through the Suez Canal, assessing the risks and cost of ship security services, calculating wind-wave losses of routes to the west and east from the island of Madagascar to the Cape of Good Hope.

\section{Research results}

IEA predicts an increase in oil consumption by 5.4 million barrels per day (up to 96.6 million barrels per day) in 2021, which will restore about $60 \%$ of the volume lost as a result of the pandemic.

According to the IEA, in the first quarter of 2021, global demand is not expected to grow; the consumption will decrease by 1 million barrels per day compared to the previous quarter (Table 1). More favorable conditions for the demand development are likely to be established in the second half of the year. In February, global oil production will decline due to Saudi Arabia's policies and the suspension of the USA capacity. OPEC forecasts that the organization members will supply 27.5

\footnotetext{
*Corresponding author: raketki08@mail.ru
} 
million barrels per day to fully meet demand in 2021 . This is about 2 million barrels per day higher than the current production, which gives a chance to weaken the OPEC+ quotas [1].

Table 1. World oil production and consumption (mln BBLpd), IEA source [1]

\begin{tabular}{|c|c|c|c|c|c|c|}
\hline & \multicolumn{4}{|c|}{2020} & \multirow{2}{*}{$\begin{array}{c}2021 \\
\text { I } \\
\text { (forecast) } \\
\end{array}$} & \multirow{2}{*}{\begin{tabular}{|l} 
I quar. \\
2021 / \\
I quar. \\
2020, \\
$\%$ \\
\end{tabular}} \\
\hline & $\mathrm{I}$ & II & III & IV & & \\
\hline \multicolumn{7}{|c|}{ Oil production } \\
\hline OPEC & 33.6 & 30.8 & 29.2 & 30.1 & & \\
\hline $\begin{array}{l}\text { Saudi } \\
\text { Arabia }\end{array}$ & 11.8 & 11.2 & 10.7 & 10.9 & & \\
\hline USA & 18.0 & 15.9 & 16.2 & 16.3 & 16.5 & -8.3 \\
\hline Russia & 11.6 & 10.4 & 10.1 & 10.4 & 10.5 & -9.7 \\
\hline World & 100.3 & 92.1 & 91.1 & 92.4 & & \\
\hline \multicolumn{7}{|c|}{ Oil consumption } \\
\hline China & 11.8 & 14.2 & 14.7 & 14.9 & 14.3 & +21.0 \\
\hline \begin{tabular}{|l} 
Europe \\
$(\mathrm{OECD})$
\end{tabular} & 13.3 & 11.0 & 12.9 & 12.5 & 12.3 & -7.6 \\
\hline USA & 19.7 & 16.4 & 18.7 & 18.8 & 18.7 & -4.9 \\
\hline World & 93.8 & 82.9 & 92.7 & 94.7 & 93.7 & -0.1 \\
\hline
\end{tabular}

The OPEC+ agreement looks quite stable, and the start of vaccination programs gives hope for the quarantine restrictions lift, borders opening and, accordingly, a consumption revival. Meanwhile, vaccination is proceeding extremely unevenly in the world and this indicates that comprehensive protection in crucial countries and regions, including the EU, cannot be completed before the summer end, which means that tourism and aviation will remain "on the ground" [1].

Despite the crisis, the dynamics of the growth and decline in oil production/consumption has not practically changed the structure of oil cargo flows (Figure 1). The main oil cargo flows in terms of transportation volume fan out from the Persian Gulf to Asia and Western Europe. Large tankers transport oil to America through African long way, smaller tankers - across the Suez Canal. Other oil cargo flows go from Latin America (Mexico, Venezuela) to the USA and Western Europe.

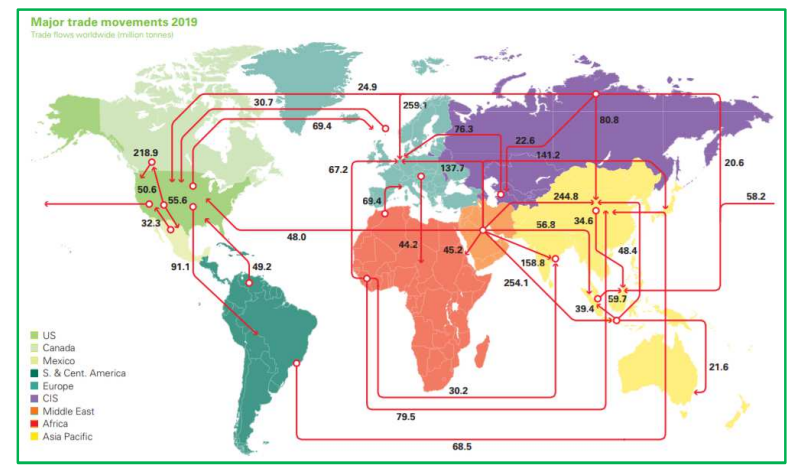

Figure 1. Major oil trade flows of the world in 2019 (mln. tons) [2]
We analyze the considered options for recommended routes along the specified transition areas in the Oceanic Ways of the World when choosing the most profitable route from the Persian Gulf to North America [3], Admiralty Ocean Passages for the World [4].

We carry out the analysis of the selected route options. Consider the features of the route first option through the Strait of Ormuz - to W from the island of Madagascar - Cape of Good Hope - Chesapeake Bay (Figures 2a, 3b, 4a, 4b).



a) Africa - Aden, Persian Gulf and Karachi;

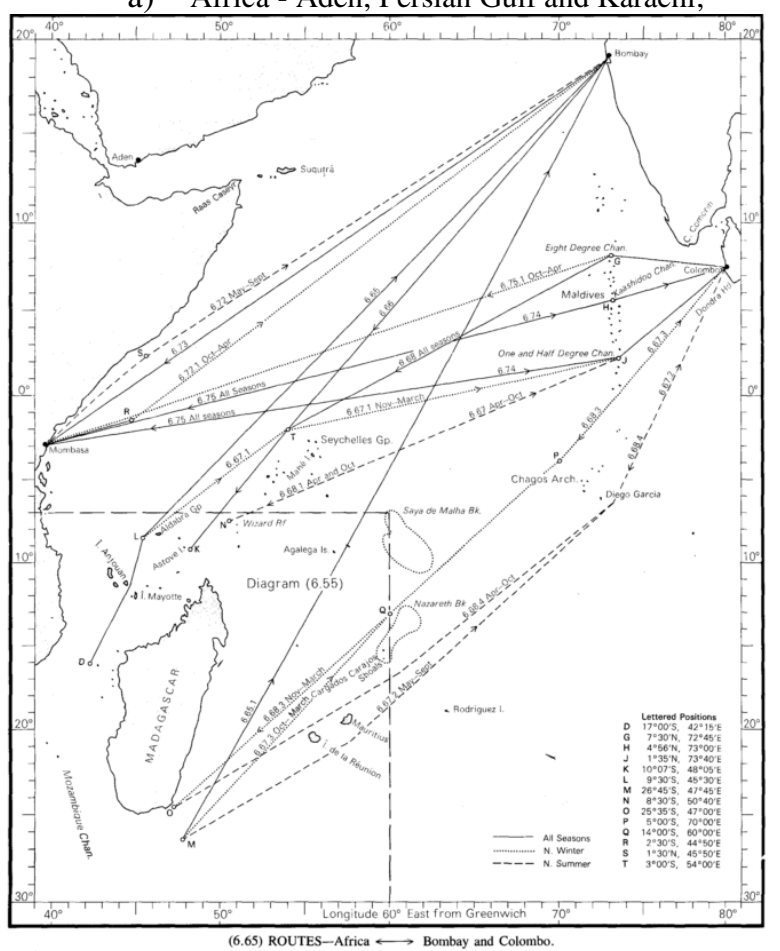

b) Africa - Bombay and Colombo

Figure 2. Sea routes of the Indian Ocean [4]. 


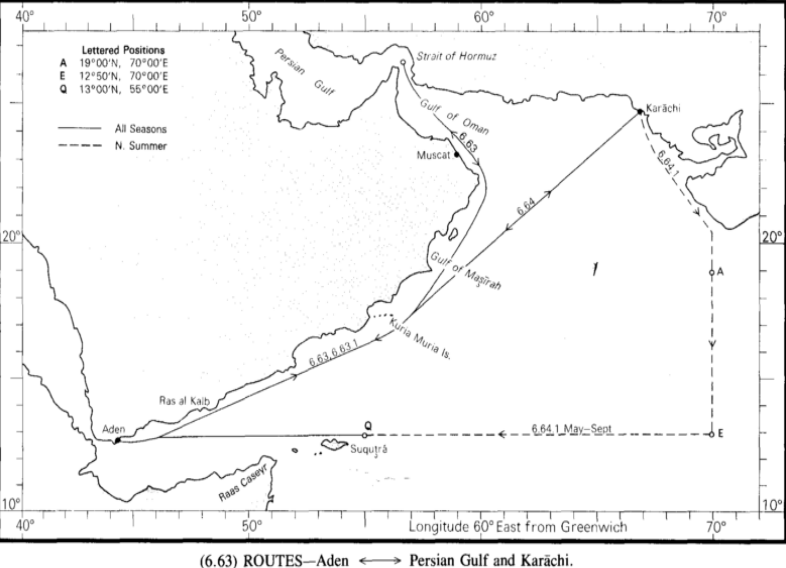

a Aden - Persian Gulf and Karachi;

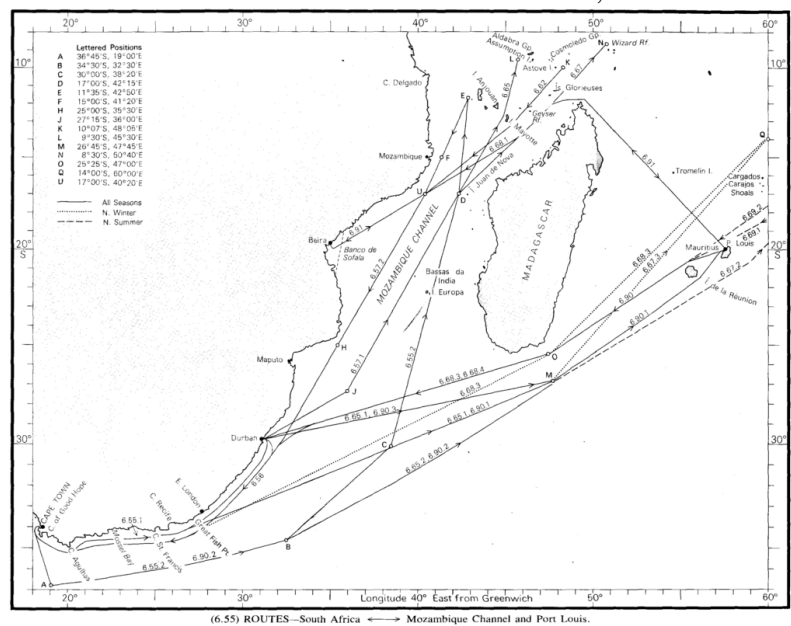

b) South Africa - Mozambique Channel and Port Louis Figure 3. Sea routes of the Indian Ocean [4].

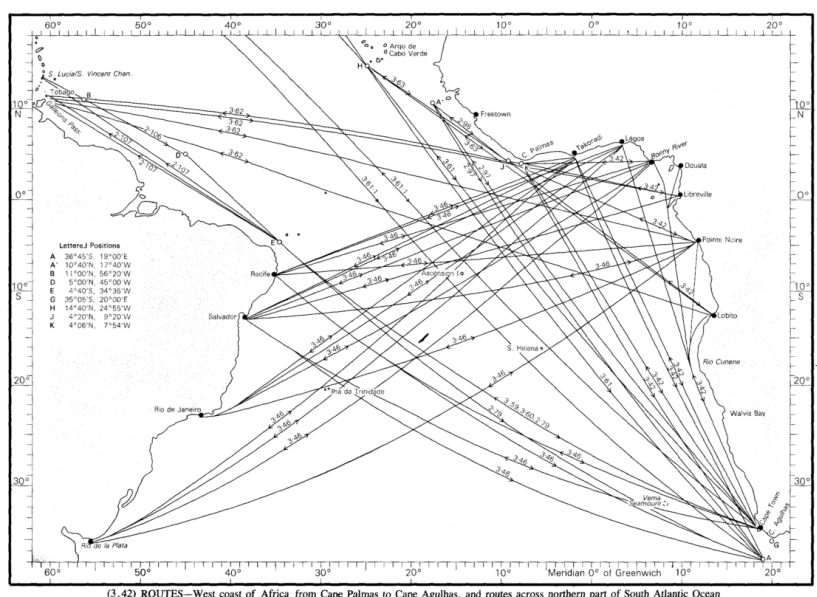

a) West African coast - Cape Palmas, Cape Agulhas and Cape Verde islands;



b) Florida Strait - Europe

Figure 4. Sea routes in the Atlantic Ocean [4].

Consider the options for the routes through the Strait of Ormuz - to E from the island of MadagascarCape of Good Hope - Chesapeake Bay (Figures 2b, 3b, $4 a, 4 b)$.

We analyze the routes through the Strait of Ormuz - Suez Canal - Mediterranean Sea - Strait of Gibraltar Chesapeake Bay (Figures 3a, 5a, 5b, 4b).

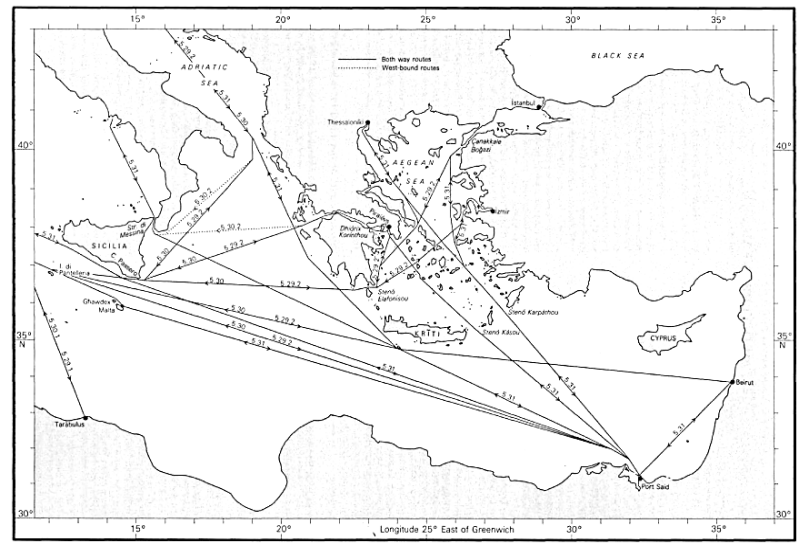

a) East Side

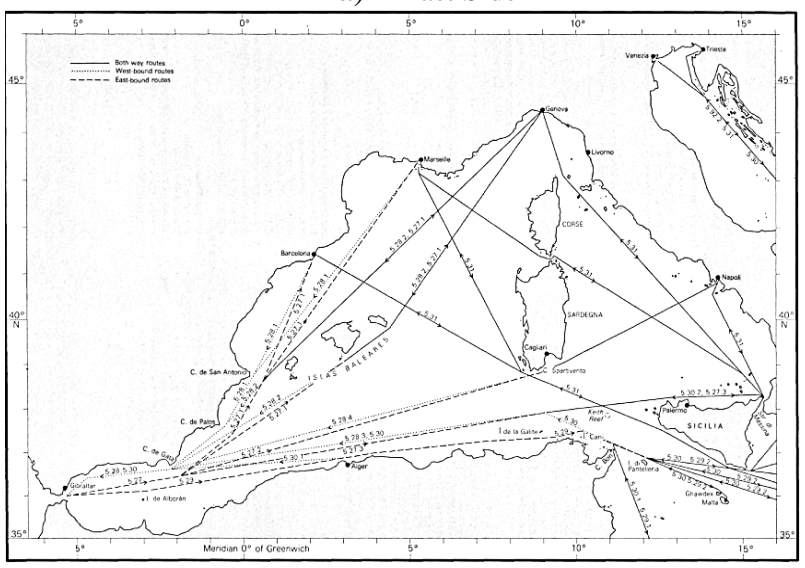

b) West Side

Figure 5. Sea routes of the Mediterranean Sea[4].

The short recommendations for calculating the distance obtained as a result of the analysis will be presented in Table 2, and we will show the selected routes in Figure 6 according to the recommendations in 
the Oceanic Ways of the World [3], Admiralty Ocean Passages for the World [4] and Ships Routeing [5].

Table 2. Recommendations and nodal points of routes

\begin{tabular}{|c|c|c|c|c|}
\hline № & $\begin{array}{c}\text { Brief recommendations for } \\
\text { choosing a route }\end{array}$ & $\begin{array}{l}\text { Nodal point } \\
\text { coordinates }\end{array}$ & & $\begin{array}{l}\text { Source/ } \\
\text { erence /page }\end{array}$ \\
\hline 1 & $\begin{array}{c}\text { Exit from TSS Cape Ras } \\
\text { El-Kuh in the Gulf of } \\
\text { Oman }\end{array}$ & $\begin{array}{c}25^{\circ} 20^{\prime} \mathrm{N}, \\
57^{\circ} 20^{\prime} \mathrm{E}\end{array}$ & [5] & $\begin{array}{c}\text { Sh.Rout/B- } \\
\text { IV/9 }\end{array}$ \\
\hline 2 & $\begin{array}{c}\text { The main path goes } \\
\text { through point to } \mathrm{N} \text { from } \\
\text { the Comoros. The eastern } \\
\text { end of Socotra Island } \\
\text { should be left at least } 50 \\
\text { miles away. }\end{array}$ & $\begin{array}{l}08^{\circ} 00^{\prime} \mathrm{N} \\
52^{\circ} 40^{\prime} \mathrm{E}\end{array}$ & [3] & $\begin{array}{c}\text { No. } 9015 / \\
6.60 / 74\end{array}$ \\
\hline 3 & $\begin{array}{l}\text { Nodal points along the east } \\
\text { coast of Africa and in the } \\
\text { Mozambique Channel }\end{array}$ & $\begin{array}{l}11^{\circ} 35^{\prime} \mathrm{S}, \\
42^{\circ} 50^{\prime} \mathrm{E} \\
13^{\circ} 35^{\prime} \mathrm{S}, \\
42^{\circ} 50^{\prime} \mathrm{E} \\
17^{\circ} 00^{\prime} \mathrm{S}, \\
40^{\circ} 20^{\prime} \mathrm{E} \\
26^{\circ} 45^{\prime} \mathrm{S}, \\
47^{\circ} 45^{\prime} \mathrm{E}\end{array}$ & [4] & $\begin{array}{l}\text { NP } 136 / \\
6 / 58 / 69 \\
6.55 / 64\end{array}$ \\
\hline 4 & $\begin{array}{c}\text { Nodal points of the route } \\
\text { to the east from the island } \\
\text { of Madagascar }\end{array}$ & $\begin{array}{l}06^{\circ} 30^{\prime} \mathrm{N} \\
60^{\circ} 00^{\prime} \mathrm{E} \\
14^{\circ} 00^{\prime} \mathrm{S} \\
60^{\circ} 00^{\prime} \mathrm{E} \\
26^{\circ} 45^{\prime} \mathrm{S} \\
47^{\circ} 45^{\prime} \mathrm{E}\end{array}$ & [4] & $\begin{array}{l}\mathrm{NP} 136 / \\
6.65 / 72 \\
6.58 / 69 \\
6.55 / 64\end{array}$ \\
\hline 5 & $\begin{array}{c}\text { Coast of South Africa. TSS } \\
\text { to S Alphard banks } \\
\text { TSS Cape Agulhas }\end{array}$ & $\begin{array}{l}34^{\circ} 45^{\prime} \mathrm{S}, \\
22^{\circ} 30^{\prime} \mathrm{E} \\
34^{\circ} 50^{\prime} \mathrm{S}, \\
21^{\circ} 40^{\prime} \mathrm{E} \\
34^{\circ} 54^{\prime} \mathrm{S}, \\
21^{\circ} 20^{\prime} \mathrm{E} \\
35^{\circ} 05^{\prime} \mathrm{S}, \\
20^{\circ} 00^{\prime} \mathrm{E}\end{array}$ & {$[5]$} & $\begin{array}{l}\text { Sh.Rout/B- } \\
\text { IV/14 } \\
\text { Sh.Rout/B- } \\
\text { IV/13 }\end{array}$ \\
\hline 6 & $\begin{array}{c}\text { South Side of the Atlantic } \\
\text { Ocean: } \\
\text { Route from the Cape of } \\
\text { Good Hope to Cape Verde } \\
\text { Islands } \\
\end{array}$ & $\begin{array}{l}35^{\circ} 05^{\prime} \mathrm{S} \\
20^{\circ} 00^{\prime} \mathrm{E} \\
14^{\circ} 40^{\prime} \mathrm{N}, \\
24^{\circ} 55^{\prime} \mathrm{W}\end{array}$ & [4] & $\begin{array}{l}\text { NP 136/ } \\
3.42 / 45\end{array}$ \\
\hline 7 & $\begin{array}{c}\text { Port Said - TSS Strait of } \\
\text { Tunis - } \\
\text { TSS Cape Gata }\end{array}$ & $\begin{array}{c}37^{\circ} 10^{\prime} \mathrm{N}, \\
11^{\circ} 20^{\prime} \mathrm{E} \\
37^{\circ} 30^{\prime} \mathrm{N}, \\
09^{\circ} 40^{\prime} \mathrm{E} \\
36^{\circ} 43^{\prime} \mathrm{N}, \\
01^{\circ} 53^{\prime} \mathrm{W} \\
36^{\circ} 36^{\prime} \mathrm{N}, \\
02^{\circ} 13^{\prime} \mathrm{W}\end{array}$ & $\begin{array}{l}{[4]} \\
{[5]} \\
{[5]}\end{array}$ & \begin{tabular}{|c} 
NP 136/ \\
$5.29 / 55$, \\
$5.30 / 54$ \\
Sh.Rout/B- \\
III/5,6 \\
Sh.Rout/B- \\
III/2
\end{tabular} \\
\hline 8 & $\begin{array}{c}\text { TSS Strait of Gibraltar - } \\
\text { TSS Oyo Bank }\end{array}$ & $\begin{array}{l}36^{\circ} 04^{\prime} \mathrm{N}, \\
05^{\circ} 15^{\prime} \mathrm{W} \\
35^{\circ} 57^{\prime} \mathrm{N}, \\
05^{\circ} 55^{\prime} \mathrm{W} \\
35^{\circ} 57^{\prime} \mathrm{N}, \\
06^{\circ} 15^{\prime} \mathrm{W}\end{array}$ & $\begin{array}{l}{[5]} \\
{[5]}\end{array}$ & $\begin{array}{l}\text { Sh.Rout/B- } \\
\text { III/1 } \\
\text { Sh.Rout/B- } \\
\text { II/28 }\end{array}$ \\
\hline 9 & the Azores & $\begin{array}{l}36^{\circ} 40^{\prime} \mathrm{N}, \\
24^{\circ} 45^{\prime} \mathrm{W}\end{array}$ & [4] & $\begin{array}{l}\text { NP } 136 / \\
2.82 / 28\end{array}$ \\
\hline 10 & $\begin{array}{c}\text { Entrance to the } \\
\text { Chesapeake Bay. TSS at } \\
\text { Cape Henry }\end{array}$ & $\begin{array}{l}36^{\circ} 50^{\prime} \mathrm{N}, \\
75^{\circ} 46^{\prime} \mathrm{W}\end{array}$ & [5] & $\begin{array}{c}\text { Sh.Rout/B- } \\
\text { IX/8 }\end{array}$ \\
\hline
\end{tabular}

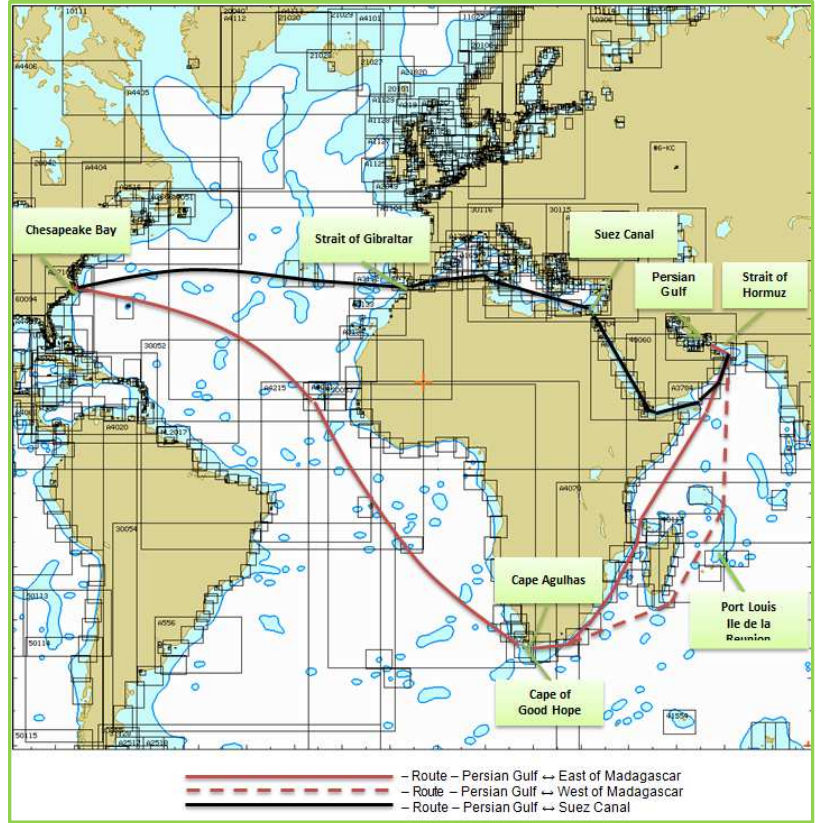

Figure 6. Selected routes from the Strait of Ormuz to the Chesapeake Bay

The calculation of the distance between the nodal points of the Strait of Ormuz (Bendar Abbas port) Chesapeake Bay (Norfolk port) is performed in the following ways: by the "BP Marine Distance Tables" electronic program, TMP-2001 (tables of sea distances) and navigation charts for routes bypassing Africa using "Navi Sailor 4000 ECDIS-I" software considering navigation criteria and weather conditions. The obtained calculation results are included in Table 3.

Table 3. Distance analysis from Bendar Abbas Port to Norfolk Port

\begin{tabular}{|c|c|c|c|c|c|}
\hline \multirow{2}{*}{ No } & \multirow{2}{*}{$\begin{array}{c}\text { Transiti } \\
\text { on } \\
\text { option }\end{array}$} & $\begin{array}{c}\text { Departure from } \\
\text { Bendar Abbas } \\
\text { Port } \\
\text { to destination } \\
\text { port of Norfolk }\end{array}$ & $\begin{array}{c}\text { Marine } \\
\text { Distance } \\
\text { Tables» }\end{array}$ & $\begin{array}{c}\text { TMP- } \\
2001\end{array}$ & $\begin{array}{c}\text { Distance } \\
\text { difference }\end{array}$ \\
\hline 1 & $\mathrm{~S}_{1}$ & $\begin{array}{c}\text { to E from } \\
\text { Madagascar }\end{array}$ & 11977 & 11929 & $\mathbf{4 8}$ \\
\hline 2 & $\mathrm{~S}_{2}$ & $\begin{array}{c}\text { to W from } \\
\text { Madagascar }\end{array}$ & 11427 & 11424 & $\mathbf{3}$ \\
\hline 3 & $\mathrm{~S}_{3}$ & The Suez Canal & 8117 & 7987 & $\mathbf{1 3 0}$ \\
\hline $\mathrm{S}_{1}-\mathrm{S}_{2}$ & $\begin{array}{c}\text { Difference in } \\
\text { favor of the } \\
\text { path to W from } \\
\text { Madagascar }\end{array}$ & $11929-11424$ & $\mathbf{5 0 5}$ \\
\hline $\mathrm{S}_{1}-\mathrm{S}_{3}$ & $\begin{array}{c}\text { Difference in } \\
\text { favor of the } \\
\text { path through } \\
\text { the Suez Canal }\end{array}$ & \multicolumn{2}{|c|}{$11424-7987$} & $\mathbf{3 4 3 7}$ \\
\hline
\end{tabular}

The calculation of distances according to "BP Marine Distance Tables" and "Tables of sea distances-2001" showed an insignificant difference in distances according to the existing tables of sea distances - 3 and 50 miles, that is, approximately 3 hours. The difference in the length of the three possible route options provide significant benefits towards 3 route options - through the Suez Canal. 
We fill in Table 4 for the analysis of routes excluding IWW, based on the basic technical parameters of the "Sea vigor" tanker of the "Suezmax" class and the calculated data on the routes going from the Strait of Ormuz to the Chesapeake Bay, that is, at $\mathrm{V}_{0}=15$ nodes, deadweight of $(\mathrm{t})=158566$ and an average fuel consumption of 40 tons per day.

From the data analysis, it follows that under favorable weather conditions, the route through the Suez

Table 4. Calculated data for routes from the Strait of Ormuz to the Chesapeake Bay

\begin{tabular}{|c|c|c|c|c|c|c|c|}
\hline Route & $\begin{array}{c}\text { Distance } \\
\text { (miles) }\end{array}$ & $\begin{array}{c}\text { Distance } \\
\text { difference }\end{array}$ & $\begin{array}{c}\text { Fuel } \\
\text { consumption (t) }\end{array}$ & $\begin{array}{c}\text { Transition } \\
\text { time }\end{array}$ & ETD & ETA & $\begin{array}{c}\text { Time } \\
\text { difference }\end{array}$ \\
\hline $\begin{array}{l}\text { to E from } \\
\text { Madagascar }\end{array}$ & 11929 & - & 1047 & \begin{tabular}{|l|}
$795.26 \mathrm{~h}$ \\
33 days $3,5 \mathrm{~h}$ \\
\end{tabular} & \begin{tabular}{|l|} 
015.03.2020 \\
10:00 UTC \\
\end{tabular} & \begin{tabular}{|l|} 
017.04.2020 \\
05:30 UTC \\
\end{tabular} & - \\
\hline $\begin{array}{l}\text { to W from } \\
\text { Madagascar }\end{array}$ & 11424 & 505 & 995 & $\begin{array}{l}761.6 \mathrm{~h} \\
31 \text { days } 18 \mathrm{~h}\end{array}$ & \begin{tabular}{|c|}
015.03 .2020 \\
10:00 UTC \\
\end{tabular} & \begin{tabular}{|l|}
016.04 .2020 \\
10:30 UTC \\
\end{tabular} & $\begin{array}{l}33.66 \mathrm{~h} \\
1 \text { day } 9.5 \mathrm{~h} \\
\end{array}$ \\
\hline \begin{tabular}{|l|} 
Through the Suez \\
Canal
\end{tabular} & 7987 & 3437 & 676 & \begin{tabular}{|l}
$532.46 \mathrm{~h}$ \\
22 days $4.5 \mathrm{~h}$
\end{tabular} & \begin{tabular}{|l|} 
015.03.2020 \\
10:00 UTC
\end{tabular} & \begin{tabular}{|l|}
06.04 .2020 \\
20:30 UTC
\end{tabular} & \begin{tabular}{|l|}
$262.8 \mathrm{~h}$ \\
10 days $23 \mathrm{~h}$ \\
\end{tabular} \\
\hline
\end{tabular}

The transit cost through the Suez Canal depends on the following factors: vessel's draft, tonnage, height of deck cargo, time of application, timeliness of the vessel's approach, direction, etc. Pilotage fees range from 8 to 12 dollars per tonne with an average cost of over 160,000 dollars per tonne to navigate [6]. The cost for a heavy cargo vessel can reach 1 million dollars or more.

Routes from the Persian Gulf are at increased risk of pirate attacks (Figure 7). According to ship owners, currently, armed guards assist on $50 \%$ of vessels crossing the Gulf of Aden and the coast of the Somali Peninsula. Generally, from 3 to 6 guards work on the vessel; they have a complete set of equipment for the job. The guard can earn from 500 to 1000 US dollars per day [8].

Guards board and disembark the vessels in Muscat and Salalah (Oman), Dar es Salaam (Tanzania), Djibouti and Galle (Sri Lanka) [8]. They stay an average of 1015 days on the vessel; the presence and provision of security services (providing the vessel with passive protection, training the crew on anti-seizure measures, equipping protected premises on the vessel) take about 100,000 dollars for the ship owner [8].

Fuel costs for the route through the Suez Canal will be US \$ 437,710 at a fuel cost of US \$ 647.5 (MGO, Fujairah, AE, [9]).

Thus, based on the averaged data, the operating costs for the Strait of Ormuz - Suez Canal - Chesapeake Bay route (duration 22 days, excluding the time spent on the Suez Canal) will be approximately 1.281.762 US dollars.
Canal is much shorter (11 days) compared to the routes through the Cape of Good Hope bypassing Africa. Accordingly, the costs of these routes are highly dependent on the duration of the voyage and fuel consumption, by about $1 / 3$.

We compare the selected routes by IWW and other economic criteria.
The cost of 31-day and 33-day flights around Africa will be estimated according to the same parameters. The outcomes are tabulated in the summary Table 5 and the difference in calculations is presented in Table 6.

The calculation result has revealed that the most expensive route is through the Suez Canal, while routes to the west and east of the island of Madagascar differ in fuel cost.

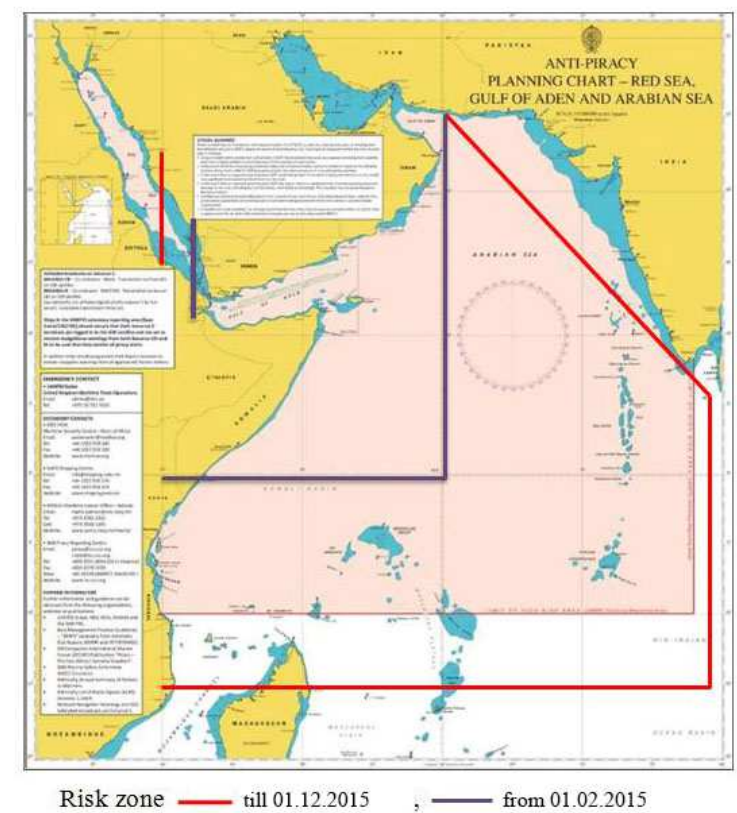

Figure 7. Borders of pirate zones [7]

Table 5. Route efficiency calculation

\begin{tabular}{|l|c|c|c|c|c|c|c|}
\hline \multicolumn{1}{|c|}{ Route } & $\begin{array}{c}\text { Distance } \\
\text { (miles) }\end{array}$ & \multicolumn{1}{|c|}{$\begin{array}{c}\text { Transition } \\
\text { time }\end{array}$} & $\begin{array}{c}\text { Fuel } \\
\text { consumption, } \\
\text { (t) }\end{array}$ & $\begin{array}{c}\text { Fuel cost } \\
(647.5 \$ / \mathrm{t})\end{array}$ & $\begin{array}{c}\text { Vessel } \\
\text { security } \\
\text { costs, }(\$)\end{array}$ & $\begin{array}{c}\text { Suez } \\
\text { transit } \\
\text { cost, }(\$)\end{array}$ & $\begin{array}{c}\text { Total } \\
\text { expenses, } \\
(\$)\end{array}$ \\
\hline $\begin{array}{l}\text { to E from } \\
\text { Madagascar }\end{array}$ & 11929 & $\begin{array}{l}795.26 \mathrm{~h} 33 \\
\text { days 3.5 h }\end{array}$ & 1047 & 677932 & 100000 & - & 777932 \\
\hline $\begin{array}{l}\text { to W from } \\
\text { Madagascar }\end{array}$ & 11424 & $\begin{array}{l}761.6 \mathrm{~h} \mathrm{31} \\
\text { days } \\
18 \mathrm{~h}\end{array}$ & 995 & 644252 & 100000 & - & 744252 \\
\hline $\begin{array}{l}\text { Through the } \\
\text { Suez Canal }\end{array}$ & 7987 & $\begin{array}{l}532.46 \mathrm{~h} \mathrm{22} \\
\text { days 4.5 h }\end{array}$ & 676 & 437710 & 100000 & 744052 & 1281762 \\
\hline
\end{tabular}


Table 6. Route cost difference

\begin{tabular}{|c|c|c|c|}
\hline $\begin{array}{c}\text { Cost } \\
\text { difference, } \\
\text { (\$) } \\
\text { Route }\end{array}$ & $\begin{array}{c}\text { to E from } \\
\text { Madagascar }\end{array}$ & $\begin{array}{c}\text { to W from } \\
\text { Madagascar }\end{array}$ & $\begin{array}{c}\text { Through } \\
\text { the Suez } \\
\text { Canal }\end{array}$ \\
\hline $\begin{array}{c}\text { to E from } \\
\text { Madagascar }\end{array}$ & - & 33680 & 503830 \\
\hline $\begin{array}{c}\text { to W from } \\
\text { Madagascar }\end{array}$ & 33680 & - & 537510 \\
\hline $\begin{array}{c}\text { Through the } \\
\text { Suez Canal }\end{array}$ & 503830 & & - \\
\hline
\end{tabular}

The calculations were based on $\mathrm{V}_{0}=15$ nodes and did not consider weather conditions. For an accurate comparison of the routes efficiency to $\mathrm{W}$ and $\mathrm{E}$ from Madagascar, we calculate wind-wave losses on each of them from the Strait of Ormuz to the Cape of Good Hope, where they are further combined into a common route to America.

The universal formula of P.M. Khokhlov is applicable for calculating the loss of vessel speed in waves. It is possible to clarify the wind-wave losses according to the formulas of V.V. Dremlyug and V.M. Shapaev on specific wind and wave conditions. Yu.I. Tulchinsky formula with a displacement accounting factor of 33,000 to 300,000 tons is suitable taking into account the deadweight of a Suezmax class tanker [10].

The coordinates of the points from the Strait of Ormuz to the Cape of Good Hope were computed using the "Navi Sailor 4000 ECDIS-I" software. The sample of the wave and flow parameters of the routes was performed in separate sections from the English sailing directions of NP 3, 33, 68, and the hydrometeorological map of the Indian Ocean No. 6311 (March) (Table 2).

The program created on the basis of VBA Visual Basic for Applications Excel 2016 was used for speed and accuracy of mathematical calculations [10]. Figures 8 and 9 represent a sample of parameters, Tables 7 and 8 - the outcomes of calculations.

Table 7. Calculated parameters for the route to $E$ from Madagascar with flows and excluding them

\begin{tabular}{|c|c|c|c|c|c|c|c|c|}
\hline \multirow{3}{*}{ Course } & \multicolumn{4}{|c|}{ Calculated parameters } & \multirow{2}{*}{$\begin{array}{l}\text { IWW without } \\
\text { flow }\end{array}$} & \multicolumn{3}{|c|}{ Calculated parameters } \\
\hline & \multirow{2}{*}{$\begin{array}{l}\text { S section, } \\
\text { miles } \\
(\mathrm{NM})\end{array}$} & $\begin{array}{c}\text { IWW without } \\
\text { flow }\end{array}$ & $\begin{array}{c}\text { IWW without } \\
\text { flow }\end{array}$ & $\begin{array}{l}\text { IWW without } \\
\text { flow }\end{array}$ & & $\begin{array}{l}\text { IWW with } \\
\text { flow }\end{array}$ & $\begin{array}{l}\text { IWW with } \\
\text { flow }\end{array}$ & $\begin{array}{l}\text { IWW rate with } \\
\text { flow }\end{array}$ \\
\hline & & $\Delta \mathrm{V}$, node & $\Delta \mathrm{t}, \mathrm{h}$ & $\mathrm{V}_{0}$ & $\mathrm{~V}_{\mathrm{m}}$ & $\Delta \mathrm{V}$, node & $\Delta \mathrm{t}, \mathrm{h}$ & $\mathrm{V}_{0}$ \\
\hline 146.1 & 39.35 & -0.07492 & -0.01317 & 14.925 & 0.5 & 0.34011 & 0.05817 & 15.340 \\
\hline 146.1 & 15.42 & -0.07492 & -0.00516 & 14.925 & 0.5 & 0.34005 & 0.02279 & 15.340 \\
\hline 140.1 & 238.40 & -0.07121 & -0.07581 & 14.929 & 0.5 & 0.31275 & 0.32460 & 15.313 \\
\hline 180.0 & 22.81 & -0.09592 & -0.00979 & 14.904 & -0.5 & -0.09634 & -0.00983 & 14.904 \\
\hline 180.0 & 2169.66 & -0.35399 & -3.49601 & 14.646 & -0.5 & -0.35421 & -3.49818 & 14.646 \\
\hline 221.9 & 1029.59 & -0.20957 & $-0 . .97256$ & 14.790 & 1.0 & -0.15527 & -0.71792 & 14.845 \\
\hline 249.1 & 1086.44 & -0.13254 & -0.64570 & 14.867 & 1.0 & -0.53942 & -2.70181 & 14.461 \\
\hline 240.4 & 141.49 & -0.30425 & -0.19529 & 14.696 & 1.5 & -0.70069 & -0.46222 & 14.299 \\
\hline 262.7 & 233.92 & -0.23300 & -0.24605 & 14.767 & 1.0 & -0.84326 & -0.92891 & 14.157 \\
\hline 262.0 & 25.45 & $-0 . .23524$ & -0.02703 & 14.765 & 1.0 & -0.83640 & -0.10017 & 14.164 \\
\hline \multirow[t]{2}{*}{242.0} & 24.36 & -0.29943 & -0.03308 & 14.701 & 1.0 & -0.59092 & -0.06660 & 14.409 \\
\hline & $\begin{array}{c}\sum \text { S,miles } \\
=5027\end{array}$ & & $\sum \mathrm{IWW}, \mathrm{h}=-5,7$ & $\mathrm{~V}_{\mathrm{m}}=14,8$ & & & $\sum \mathrm{IWW}, \mathrm{h}=-8,1$ & $\mathrm{~V}_{\mathrm{m}}=14,7$ \\
\hline $\begin{array}{l}\text { Crossing } \\
\text { time }\end{array}$ & \multicolumn{4}{|c|}{ Without flow $\mathrm{t}, \mathrm{h}=339.6 \mathrm{~h}=14$ days $4 \mathrm{~h}$} & & \multicolumn{3}{|c|}{ With flow $\mathrm{t}, \mathrm{h}=341.9 \mathrm{~h}=14$ days $6 \mathrm{~h}$} \\
\hline
\end{tabular}

Table 8. Calculated parameters for the route to $\mathrm{W}$ from Madagascar with flows and excluding them

\begin{tabular}{|c|c|c|c|c|c|c|c|c|}
\hline \multirow{3}{*}{ Course } & \multicolumn{4}{|c|}{ Calculated parameters } & \multirow[b]{2}{*}{$\begin{array}{l}\text { IWW without } \\
\text { flow }\end{array}$} & \multicolumn{3}{|c|}{ Calculated parameters } \\
\hline & \multirow{2}{*}{$\begin{array}{l}\text { S section, } \\
\text { miles } \\
(\mathrm{NM})\end{array}$} & $\begin{array}{l}\text { IWW without } \\
\text { flow }\end{array}$ & $\begin{array}{l}\text { IWW without } \\
\text { flow }\end{array}$ & $\begin{array}{l}\text { IWW without } \\
\text { flow }\end{array}$ & & $\begin{array}{l}\text { IWW with } \\
\text { flow }\end{array}$ & $\begin{array}{l}\text { IWW with } \\
\text { flow }\end{array}$ & $\begin{array}{l}\text { IWW rate with } \\
\text { flow }\end{array}$ \\
\hline & & $\Delta \mathrm{V}$, node & $\Delta \mathrm{t}, \mathrm{h}$ & $\mathrm{V}_{0}$ & $\mathrm{~V}_{\mathrm{m}}$ & $\Delta \mathrm{V}$, node & $\Delta \mathrm{t}, \mathrm{h}$ & $\mathrm{V}_{0}$ \\
\hline \begin{tabular}{|l|}
146.1 \\
\end{tabular} & $39 . .30$ & -0.07492 & -0.01315 & 14.925 & 0.5 & 0.34026 & 0.05812 & 15.340 \\
\hline \begin{tabular}{|l|l}
146.1 \\
\end{tabular} & 15.46 & -0.07492 & -0.00517 & 14.925 & 0.5 & 0.34010 & 0.02285 & 15.340 \\
\hline \begin{tabular}{|l|}
140.1 \\
\end{tabular} & 238.41 & -0.07121 & -0.07582 & 14.929 & 0.5 & 0.31271 & 0.32458 & 15.313 \\
\hline \begin{tabular}{|l|}
180.0 \\
\end{tabular} & 22.94 & -0.09592 & -0.00984 & 14.904 & -0.5 & 0.25710 & 0.02577 & 15.257 \\
\hline 204.0 & 632.13 & -0.42107 & -1.21714 & 14.579 & -1.5 & 0.97854 & 2.58079 & 15.979 \\
\hline \begin{tabular}{|l|}
207.7 \\
\end{tabular} & 1634.43 & -0.41144 & -3.07305 & 14.589 & -1.0 & 0.54301 & 3.80670 & 15.543 \\
\hline 203.1 & 222.93 & -0.27921 & -0.28189 & 14.721 & 0.5 & 0.18058 & 0.17679 & 15.181 \\
\hline 205.7 & 133.14 & -0.27119 & -0.16343 & 14.729 & 1.0 & 0.63011 & 0.35783 & 15.630 \\
\hline \begin{tabular}{|l|}
209.4 \\
\end{tabular} & 551.10 & -0.25931 & -0.64632 & 14.741 & 1.5 & 0.14398 & 0.34929 & 15.144 \\
\hline \begin{tabular}{|l|}
215.5 \\
\end{tabular} & 478.66 & -0.38448 & -0.83945 & 14.616 & 1.5 & -0.13464 & -0.28903 & 14.865 \\
\hline \begin{tabular}{|l|}
223.4 \\
\end{tabular} & 61.87 & -0.35881 & -0.10109 & 14.641 & 1.5 & -0.31480 & -0.08842 & 14.685 \\
\hline \begin{tabular}{|l|}
224.5 \\
\end{tabular} & 84.07 & -0.35528 & -0.13596 & 14.645 & 1.5 & -0.34059 & -0.13021 & 14.659 \\
\hline \begin{tabular}{|l|}
240.4 \\
\end{tabular} & 141.49 & -0.30392 & -0.19508 & 14.696 & 1.5 & -0.70037 & -0.46200 & 14.300 \\
\hline \begin{tabular}{|l|}
262.7 \\
\end{tabular} & 233.92 & -0.23300 & -0.24605 & 14.767 & 1.0 & -0.84326 & -0.92891 & 14.157 \\
\hline \begin{tabular}{|l|}
263.3 \\
\end{tabular} & 25.45 & -0.23524 & -0.02703 & 14.765 & 1.0 & -0.85376 & -0.10240 & 14.146 \\
\hline \begin{tabular}{|l|}
240.8 \\
\end{tabular} & 24.56 & -0.29943 & -0.03335 & 14.701 & 1.0 & -0.57051 & -0.06474 & 14.429 \\
\hline & $\sum \mathrm{S}, \mathrm{miles}=4540$ & & $\sum \mathrm{IWW}, \mathrm{h}=-7,1$ & $\mathrm{~V}_{\mathrm{m}}=14.7$ & & & $\sum \mathrm{IWW}, \mathrm{h}=5.6$ & $\mathrm{~V}_{\mathrm{m}}=14.99$ \\
\hline Cro & ssing time & Without fl & $\mathrm{v} \mathrm{t}, \mathrm{h}=308.8 \mathrm{~h}=1$ & days $21 \mathrm{~h}$ & & With fl & $\mathrm{vt}, \mathrm{h}=302.9 \mathrm{~h}=$ & 2 days $15 \mathrm{~h}$ \\
\hline
\end{tabular}


The flow rates on the routes are relatively small (according to hydrometeorological data do not exceed 0.5-1.0 nodes - Tables 7, 8). The flow directions in the sections are both on-coming and passing. The highest flow rate in the Mozambique Channel is up to $1 \frac{1}{2}$ nodes, which makes this crossing section an advantageous not only in time, but also in rate. The gain in time will be approximately 2 days subject to the passing flow in the Mozambique Channel and the current of Cape Agulhas.

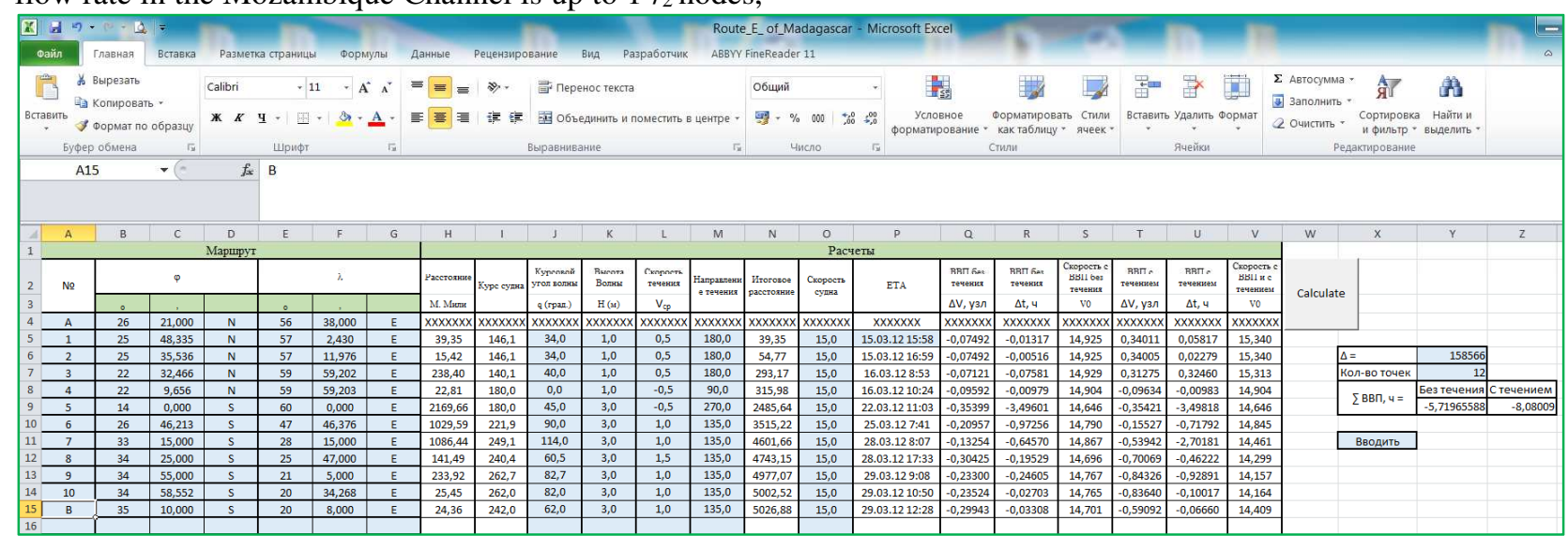

a) on the route to E from Madagascar

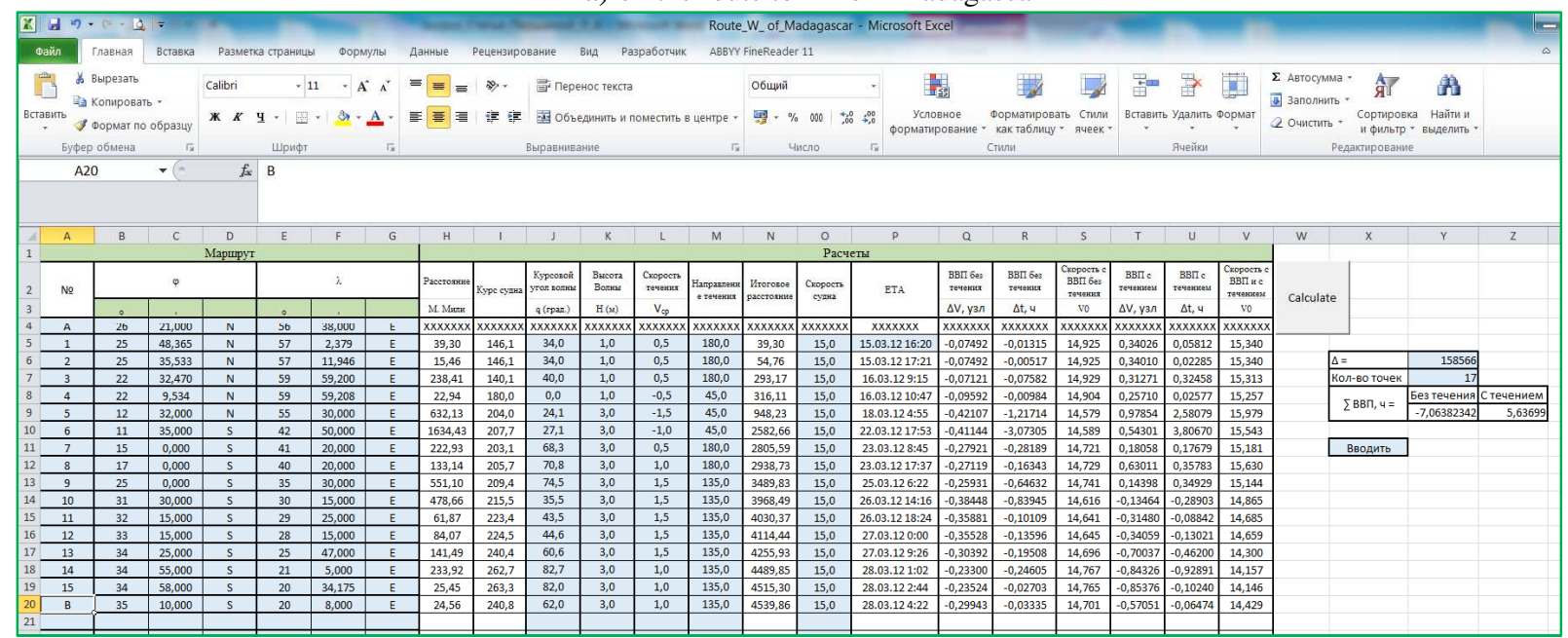

b) on the route to $\mathrm{W}$ from Madagascar

Figure 8. Table of input and calculation data

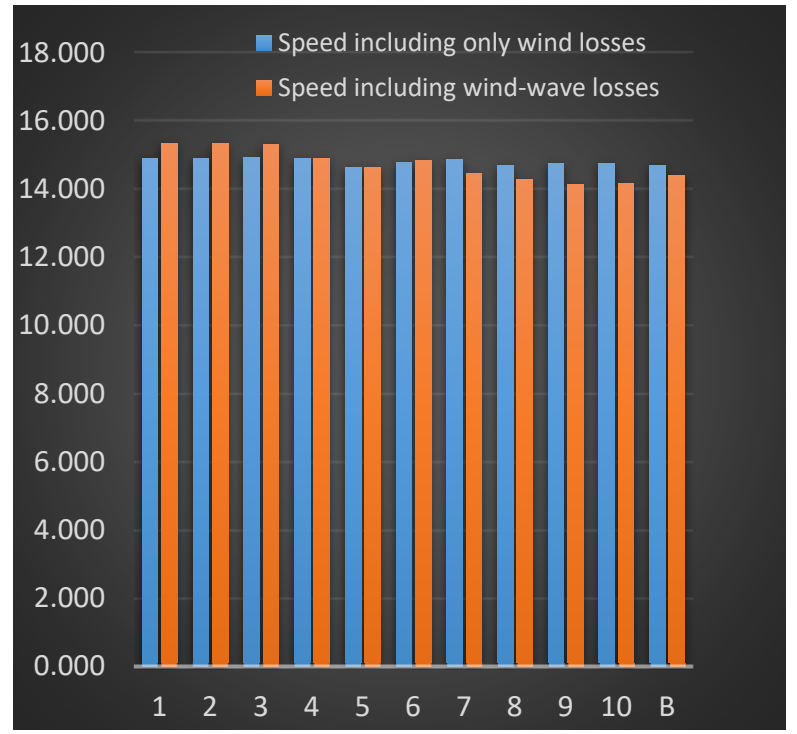

a) on the route to $\mathrm{E}$ from Madagascar

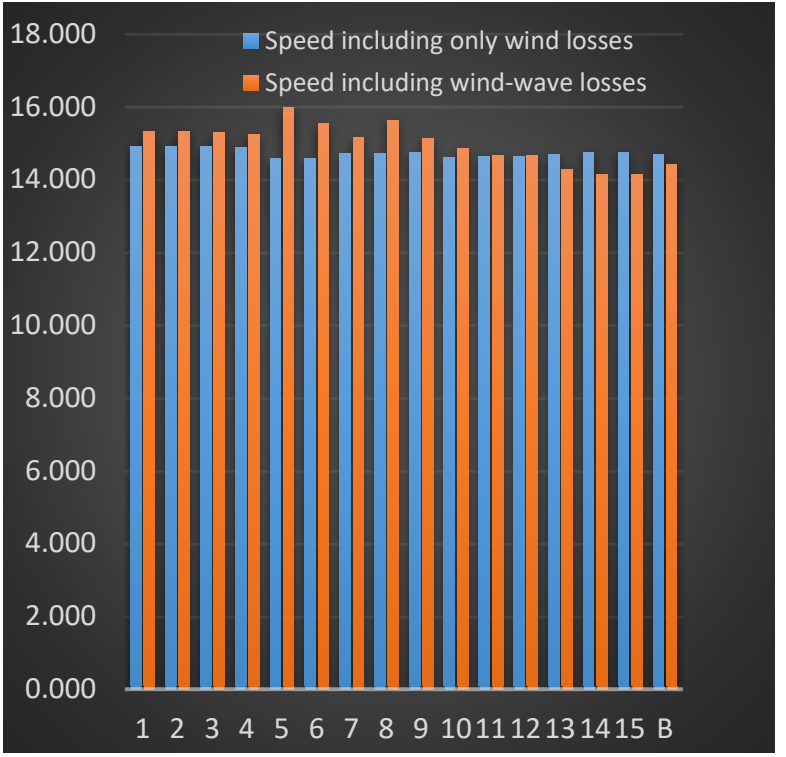

b) on the route to $\mathrm{W}$ from Madagascar

Figure 9. Comparison diagrams of wind-wave losses without regard to flows and with them: 
The variation range of wind and wave losses is insignificant - 0.1-0.2 nods on each route. The gain in time arises only on certain sections of the route, which, according to Student's theory, do not differ significantly despite the disagreements (Diagrams - Figure 9), and are practically homogeneous (Wilcoxon test).

\section{Conclusion}

The research outcome has proven that the shortest timing route is the most expensive one (Figure 10). It can be profitable on a short haul for transportation to the countries of the Mediterranean Basin and Western Europe on vessels of the LRl, MR, Handymax, Handysize classes reducing the amount of road charge through the Suez due to tonnage. At the same time, it is feasible to perform two or three voyages per month, and, accordingly, get an income for freight two to three times more.

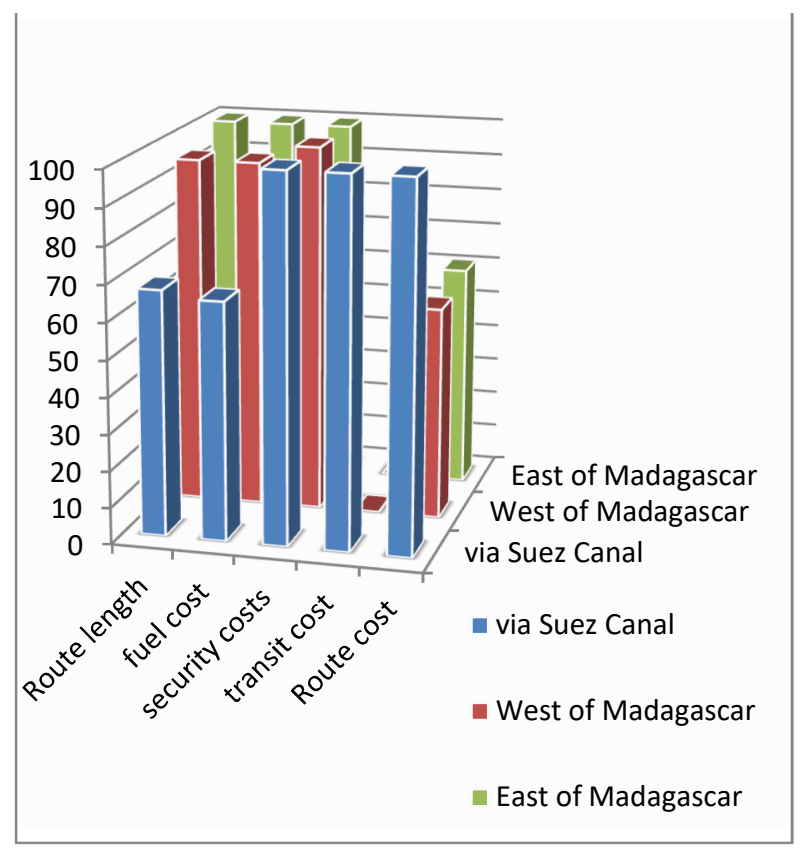

Figure 10. Efficiency diagram of routes from the Strait of Ormuz to the Chesapeake Bay, \%

The Suez Canal Administration is going for significant discounts during a pandemic and a global decline in fuel prices, especially for long-distance routes to America and the Caribbean and for large vessels of the VLCC class. Such concessions ensure the flow of large-tonnage vessels through the Suez Canal, since the canal capacity after reconstruction doubles up to 5.8 million tons per day. Moreover, the number of vessels increased by a third - from 45-60 to 75 vessels in both directions [6].

Meanwhile, tankers of the VLCC and Suezmax class prefer to use longer routes (11 days) bypassing Africa, because the total cost of cargo delivery is about $40 \%$ less.
If one chooses between the route to the west or east of Madagascar in accordance with the hydrometeorological data for March, today the western route along the African coast is more profitable for a number of reasons. Firstly, the crossing time is 31-39 hours shorter, depending on the flow. Secondly, the difference in wind-wave losses is minor - 0.1-0.2 nodes, and due to the flow, is reduced to zero. Thirdly, the route has become less dangerous compared to 2014-2018 with respect to the vessels escort under protection and a decrease in the risk of pirate attacks.

Routes to the east of Madagascar passes through the "open sea", bypassing pirate-hazardous areas from the archipelagos and the coastal zone, and the routes are safer depending on seasonal conditions (tropical cyclones).

In conclusion, the reasons that form the main traffic of oil and oil products in the Indian Ocean can be singled out:

- presence of deposits in the Arabian Peninsula and the Persian Gulf;

- direction of transportation: to Asia, Europe or America;

- vessel tonnage and voyage assignment;

- voyage duration and costs of fuel, wages, downtime, etc.;

- road charges arising from the passage of limiting sections;

- hydrometeorological conditions at the route time ensuring safe vessel pilotage;

- risk assessment of piracy on the route and the resulting inevitable costs of ship owners for vessel security and insurance of the crew, vessel, cargo;

- socioeconomic conditions, sometimes dramatically changing the market conditions and even the wellestablished seasonal routes of the World ocean.

\section{References}

1. Energy Bulletin. 93, 2-8, (2021) Available at: https://ac.gov.ru/uploads/2Publications/energo/energo_dec_2020.pdf

2. BP Statistical Review of World Energy. Available at: https://www.bp.com/content/dam/bp/businesssites/en/global/corporate/pdfs/energyeconomics/statistical-review/bp-stats-review2020-full-report.pdf

3. Ocean paths of the world 9015 (Main Directorate of Navigation and Oceanography of the Ministry of Defense, 1980)

4. Admiralty Ocean Passages for the World (United Kingdom Hydrographic Office, 2004).

5. Ships' Routing. (IMO, 2015).

6. Road charge calculator. Available at: https://www.suezcanal.gov.eg/English/Navigation /Tolls/Pages/TollsTable.aspx.

7. L. Astreina, L. Pershina. Operation of marine transport, 4 (85), 68-74. Available at: https://aumsu.ru/images/sbornik/vypuski/emt_4_2 017.pdf 
8. Navy. 2012. 5. Available at: http://www.morvesti.ru/themes/1700/53367/

9. World bunker prices. Available at: http://www.mabux.ru/bunkerprices/index.jsp.

10. L. Pershina. Operation of marine transport, 2

(87), PP. 58-66. Available at: https://aumsu.ru/images/sbornik/vypuski/_2_2018 .pdf 